\title{
Hypothesis: may e-cigarette smoking boost the allergic epidemic?
}

\author{
Jean Bousquet ${ }^{1,2,3,4,9^{*}}$, Claus Bachert ${ }^{5}$, Laura Crotty Alexander ${ }^{6,7}$ and Frank T. Leone ${ }^{8}$
}

\section{Background}

IgE-associated allergic diseases represent a global health problem increasing in prevalence and severity. An epidemic of IgE-associated allergic diseases has occurred over the past decades globally $[1,2]$ and many factors driving this epidemic are not clear. The most common diseases (asthma, rhinitis and eczema) are linked, at least partly, to IgE immune response. These diseases are complex multifactorial disorders, with both genetic and environmental components. Reasons explaining the allergy epidemic are not clear. Many inhalants such as air pollution and diesel exhaust particulates are associated with a modulation of the IgE response [3]. On the other hand, tobacco smoking has a minimal effect on the increased prevalence or severity of allergic rhinitis [4].

Any new inhaled compound should be considered a potential adjuvant of the IgE immune response or nonallergic mechanisms leading to a boost in the allergy epidemic. E-cigarettes are largely used to replace conventional cigarette smoking with the intention to reduce known risks for smokers' health; however, many side effects may still be unknown. Here we focus on the question of whether allergy may be theoretically associated with e-cigarette use.

\section{E-cigarette vaping}

The behaviour of smoking is a cardinal sign of a complex, biosocial compulsive disorder of the brain-a disorder induced by repeated exposure to nicotine [5]. As a result, the global tobacco epidemic claims nearly 6 million lives annually, despite a near-universal appreciation of the catastrophic health consequences of continued use [6]. Ambivalence, or the continuation of maladaptive behaviours in the face of a rational desire to stop, is

\footnotetext{
*Correspondence: jean.bousquet@orange.fr

${ }^{9} \mathrm{CHRU}$ Arnaud de Villeneuve, 371 Avenue du Doyen Gaston Giraud,

34295 Montpellier Cedex 5, France

Full list of author information is available at the end of the article
}

the hallmark of nicotine dependence, and is frequently resolved by adopting compromise positions, including the use of "light" or filtered cigarettes [7].

The electronic cigarette, or "e-cigarette", is the latest addition to the list of available compromise products introduced to western markets by the industry. A wide variety of devices are available, with an array of design features and constituent components that significantly influence the pharmacologic/toxicologic profile of each device [8]. Though the devices vary greatly in technical specifications, they most commonly deliver a nicotinecontaining aerosol to the aeropharyngeal mucosa, and have been heavily marketed as healthier alternatives to tobacco smoking. In addition to varying amounts of nicotine, the aerosol also delivers propylene glycol and vegetable glycerin, humectants used as a stabilizing vehicle and to create the appearance of smoke plumes, and one or more flavourant additives to increase the appeal of the product [9].

Precisely because the consequences of conventional smoking are so serious, it has been easy for e-cigarette users [10], physicians [11], and at least one professional society [12] to explicitly judge these electronic nicotine delivery devices to be safer than cigarettes. In fact, e-cigarette aerosols do contain far lower concentrations of common cigarette carcinogens on average $[13,14]$. However, what is true of the average is not true of the individual products [15]. Neither is it true that carcinogenesis is the sole hazard presented by the aerosol. A growing body of evidence suggests that e-cigarette aerosol constituents may have their own unique hazard profile, distinct from that expected from smoke. For example, a number of disturbances in airway epithelial, endothelial, and inflammatory regulatory physiology have been identified, with uncertain implications on long term health [16, 17].

In high school students in South Korea, e-cigarette users have an increased association with asthma and are more likely to have had days absent from school due to severe asthma symptoms [18]. 


\section{Effects of e-cigarettes on human host defence and bacterial virulence}

E-cigarette vapor inhaled into human airways interacts with several types of cells, including epithelial and macrophages. Exposure of human cells to e-cigarette vapor has been found to alter innate immune responses and inflammatory signaling [17, 19-22]. In this way, e-cigarette use may induce inflammatory lung diseases or increase susceptibility to invasive bacterial pathogens by effects on mammalian airway cells. Acute e-cigarette vapor inhalation has been found to alter airway physiology: 5 min of e-cigarette use increased airways resistance and lowered the fractional exhalation of nitric oxide (NO), both of which suggest activation of pathways known to be important in asthma [23].

Mammalian cells are not the only residents of human airways. Bacterial pathogens such as Staphylococcus aureus (S. aureus) commonly colonize the airways and are exposed to inhalants. E-cigarette exposure imposes stress on $S$. aureus, inducing changes in the surface charge, hydrophobicity, and biofilm formation. Nicotine alone had subtle effects, while both aerosolized propylene glycol and vegetable glycerin had dramatic effects on bacterial pathogenicity, independently or when used together. Changes induced by e-cigarette vapor improved the ability of $S$. aureus to adhere to and invade epithelial cells, and increased resistance to human antimicrobial peptides. When unflavored e-cigarette vapor exposed $S$. aureus were introduced into mouse lungs, increased virulence was found via increased bacteria within lung parenchyma and increased mortality $[17,21]$. Thus, the use of e-cigarettes may increase the incidence and severity of bacterial lung infections by both direct effects on human cells of host defense as well as effects on bacterial cells. It is unknown whether flavorants will also have provirulent effects on bacteria.

\section{Staphylococcus sensitization and allergic diseases}

Staphylococcus aureus is a frequent colonizer of the upper and lower airways and the skin. In the nose, it may form biofilms and resides intramucosally, and has been associated with different types of $\mathrm{T}$ helper cell reactions; recently, arguments for a role also in Th2 immune diseases such as chronic rhinosinusitis and asthma accumulate [24]. S. aureus forms a rich immune proteome, with more than 1500 different proteins comprising virulence factors, enterotoxins including classical superantigens, and proteins with enzymatic properties. Whereas the classical enterotoxins may activate $\mathrm{T}$ cell populations unspecifically via the variable $B$-chain of $\mathrm{T}$ cell receptors, other recently discovered molecules such as serine protease-like proteins (spls) obviously elicit a strong Th2-biased immune response and act as allergens or super-allergens, as they induce IgE formation also to inert proteins [25]. Spl-specific memory $\mathrm{T}$ cells elaborate Th2 cytokines including IL-4, IL-5 and IL-13, whereas small amounts of IFN- $\gamma$, IL-6, TNF and IL-17 are produced. IL-4 and IL-13 drive the immunoglobulin class switch to IgE, and IL-5 orchestrates activation and survival of eosinophils. Both protein families, enterotoxins and spls, have been found in human airway mucosa, and elicit, when given intra-tracheal in mice, an allergic lung inflammation. A typical hallmark of Th2 reactions is the formation of IgE; in the presence of staphylococcal superantigens, a polyclonal IgE formation is regularly found including several IgE antibodies directed towards classical and ECG-locus enterotoxins (SE-IgEs); the latter are indicators of a manifest immune reaction to $S$. aureus products. SE-IgE was significantly associated with asthma in 3000 Europeans [26] and was shown to be linked to severe asthma, atopic or non-atopic, both in European [27] and Asian populations [28]. MeDALL (Mechanisms of the Development of Allergy) proposed that S. aureus sensitization was associated with a re-occurrence of foetal Type 2 signalling leading to the onset of IgE and nonIgE dependent diseases $[29,30]$.

\section{From a hypothesis to public health strategies}

The hypothesis that e-cigarette increases $S$. aureus colonisation and then induces sensitization is important to consider since $S$. aureus colonisation is needed for the development of an IgE immune response that is often associated with a polyclonal IgE response, allergic symptoms of the upper and lower airways including allergic rhinitis, severe asthma and/or chronic rhinosinusitis with nasal polyposis.

Although currently there is no confirmation that e-cigarette smoking may induce allergic diseases, there is sufficient background to seriously consider this hypothesis and to test it in appropriate cross-sectional and longitudinal epidemiologic studies. If the effect on $S$. aureus colonisation is important in e-cigarette users, the proofof-concept should already be demonstrable, as e-cigarettes were introduced to the international market in 2007 and now are used by upwards of $10 \%$ of US, European and Asian populations [31]. One possible differentiating feature of e-cigarette-induced allergy would be that users may be prone to develop polysensitization whereas people developing allergic sensitization in adulthood are more often monosensitized or oligosensitized [32].

The next important step will be the identification of e-cigarette components which may induce allergic mechanisms: propylene glycol, glycerine, nicotine, flavorants or toxins produced by the aerosolization process. Animal studies may help guide human studies by narrowing the field of relevant e-cigarette components, defining 
molecular pathways affected by e-cigarette vapor, and assessing duration and extent of exposure needed to confer increased risk of allergic disease. Large human trials will then be needed to confirm findings with a sufficient power to discriminate between the different types of e-cigarettes.

The most difficult task will be to derive health promotion strategies from this hypothesis. Proponents of e-cigarettes will indicate that allergy and asthma are trivial diseases by comparison to putative cancer prevention [12, 31, 33]. Opponents to e-cigarettes will take the asthma example as a major adverse health consequence of e-cigarette vapor inhalation. In any case, removal of the IgE-promoting components will be needed.

In conclusion, it is urgent to confirm or refute this hypothesis using appropriate studies.

\section{Abbreviations}

IFN: interferon; IL: interleukin; NO: nitric oxide; S. aureus: Staphylococcus aureus; Spls: serine protease-like proteins; Th2:T helper 2; TNF: tumor necrosis factor.

\section{Authors' contributions}

During a meeting two authors (JB, FL) discussed the topic and all met by Skype to write the editorial. All authors wrote a section of the paper. Al authors read and approved the final manuscript.

\section{Author details \\ ${ }^{1}$ University Hospital, Montpellier, France. ${ }^{2}$ MACVIA-France, Contre les MAla- dies Chroniques pour un Vleillissement Actif en France, European Innovation Partnership on Active and Healthy Ageing Reference Site, Montpellier, France. ${ }^{3}$ INSERM, VIMA: Ageing and Chronic Diseases, Epidemiological and Public Health Approaches, U1 168, Paris, France. ${ }^{4}$ UVSQ, UMR-S 1168, Université Versailles St-Quentin-en-Yvelines, Versailles, France. ${ }^{5}$ University Hospital Ghent, Ghent, Belgium. ${ }^{6}$ VA San Diego Healthcare System, San Diego, CA, USA. ${ }^{7}$ Uni- versity of California San Diego, San Diego, CA, USA. ${ }^{8}$ University of Pennsylva- nia, Philadelphia, PA, USA. ${ }^{9}$ CHRU Arnaud de Villeneuve, 371 Avenue du Doyen Gaston Giraud, 34295 Montpellier Cedex 5, France.}

\section{Acknowledgements}

None.

\section{Competing interests}

The authors declare that they have no competing interests.

Received: 22 September 2016 Accepted: 1 November 2016 Published online: 15 November 2016

\section{References}

1. Bousquet J, Anto J, Auffray C, Akdis M, Cambon-Thomsen A, Keil T, et al. MeDALL (Mechanisms of the Development of ALLergy): an integrated approach from phenotypes to systems medicine. Allergy. 2011:66(5):596-604

2. 2008-2013 Action plan for the global strategy for the prevention and control of non communicable diseases. Prevent and control cardiovascular diseases, cancers, chronic respiratory diseases, diabetes. http://www. whoint/nmh/Actionplan-PC-NCD-2008pdf. 2008

3. Behrendt H, Alessandrini F, Buters J, Kramer U, Koren H, Ring J. Environmental pollution and allergy: historical aspects. Chem Immunol Allergy. 2014;100:268-77.

4. Saulyte J, Regueira C, Montes-Martinez A, Khudyakov P, Takkouche B. Active or passive exposure to tobacco smoking and allergic rhinitis, allergic dermatitis, and food allergy in adults and children: a systematic review and meta-analysis. PLoS Med. 2014;11(3):e1001611.

5. Dingel MJ, Karkazis K, Koenig BA. Framing nicotine addiction as a "disease of the brain": social and ethical consequences. Soc Sci Q. 2012;92(5):1363-88

6. WHO|WHO report on the global tobacco epTIOAmic, 2011: warning about the dangers of tobacco. http://www.whoint/tobacco/global report/2011/en/indexhtml. 2011.

7. Leone FT, Evers-Casey S. Developing a rational approach to tobacco use treatment in pulmonary practice: a review of the biological basis of nicotine addiction. Clin Pulm Med. 2012:19(2):53-61.

8. Grana R, Benowitz N, Glantz SA. E-cigarettes: a scientific review. Circulation. 2014;129(19):1972-86.

9. Drummond MB, Upson D. Electronic cigarettes. Potential harms and benefits. Ann Am Thorac Soc. 2014;11(2):236-42.

10. Li J, Bullen C, Newcombe R, Walker N, Walton D. The use and acceptability of electronic cigarettes among New Zealand smokers. N Z Med J. 2013:126(1375):48-57.

11. Kandra KL, Ranney LM, Lee JG, Goldstein AO. Physicians' attitudes and use of e-cigarettes as cessation devices, North Carolina, 2013. PLoS ONE. 2014;9(7):e103462.

12. Nutt DJ, Phillips LD, Balfour D, Curran HV, Dockrell M, Foulds J, et al. Estimating the harms of nicotine-containing products using the MCDA approach. Eur Addict Res. 2014;20(5):218-25.

13. Goniewicz ML, Lingas EO, Hajek P. Patterns of electronic cigarette use and user beliefs about their safety and benefits: an internet survey. Drug Alcohol Rev. 2013;32(2):133-40.

14. Sleiman M, Logue JM, Montesinos VN, Russell ML, Litter MI, Gundel LA, et al. Emissions from electronic cigarettes: key parameters affecting the release of harmful chemicals. Environ Sci Technol. 2016;50(17):9644-51.

15. Kosmider L, Sobczak A, Fik M, Knysak J, Zaciera M, Kurek J, et al. Carbonyl compounds in electronic cigarette vapors: effects of nicotine solvent and battery output voltage. Nicot Tob Res. 2014;16(10):1319-26.

16. Rowell TR, Tarran R. Will chronic e-cigarette use cause lung disease? Am J Physiol Lung Cell Mol Physiol. 2015;309(12):L1398-409.

17. Hwang JH, Lyes M, Sladewski K, Enany S, McEachern E, Mathew DP, et al. Electronic cigarette inhalation alters innate immunity and airway cytokines while increasing the virulence of colonizing bacteria. J Mol Med (Berl). 2016;94(6):667-79.

18. Cho JH, Paik SY. Association between electronic cigarette use and asthma among high school students in South Korea. PLOS ONE. 2016:11(3):e0151022.

19. Sussan TE, Gajghate S, Thimmulappa RK, Ma J, Kim JH, Sudini K, et al. Exposure to electronic cigarettes impairs pulmonary antibacterial and anti-viral defenses in a mouse model. PLOS ONE. 2015;10(2):e0116861.

20. Lim HB, Kim SH. Inhallation of e-cigarette cartridge solution aggravates allergen-induced airway inflammation and hyper-responsiveness in mice. Toxicol Res. 2014:30(1):13-8.

21. Hwang JH, Lyes M, Sladewski K, Enany S, McEachern E, Mathew DP, et al. Electronic cigarette inhalation alters innate immunity and airway cytokines while increasing the virulence of colonizing bacteria. J Mol Med (Berl). 2016:94(6):667-79.

22. Wu Q, Jiang D, Minor M, Chu HW. Electronic cigarette liquid increases inflammation and virus infection in primary human airway epithelial cells. PLOS ONE. 2014;9(9):e108342.

23. Vardavas $\mathrm{Cl}$, Anagnostopoulos N, Kougias M, Evangelopoulou V, Connolly GN, Behrakis PK. Short-term pulmonary effects of using an electronic cigarette: impact on respiratory flow resistance, impedance, and exhaled nitric oxide. Chest. 2012;141(6):1400-6.

24. Bachert C, Zhang N. Chronic rhinosinusitis and asthma: novel understanding of the role of IgE 'above atopy.'. I Intern Med. 2012;272(2):133-43.

25. Stentzel S, Teufelberger A, Nordengrun M, Kolata J, Schmidt F, van Crombruggen $\mathrm{K}$, et al. Staphylococcal serine protease-like proteins are pacemakers of allergic airway reactions to Staphylococcus aureus. J Allergy Clin Immunol. 2016. doi:10.1016/j.jaci.2016.03.045.

26. Tomassen P, Jarvis D, Newson R, Van Ree R, Forsberg B, Howarth $P$ et al. Staphylococcus aureus enterotoxin-specific lgE is associated with asthma in the general population: a GA(2)LEN study. Allergy. 2013:68(10):1289-97. 
27. Bachert C, van Steen K, Zhang N, Holtappels G, Cattaert T, Maus B, et al. Specific IgE against Staphylococcus aureus enterotoxins: an independent risk factor for asthma. J Allergy Clin Immunol. 2012;130(2):376-81.

28. Song WJ, Sintobin I, Sohn KH, Kang MG, Park HK, Jo EJ, et al. Staphylococcal enterotoxin IgE sensitization in late-onset severe eosinophilic asthma in the elderly. Clin Exp Allergy. 2016;46(3):411-21.

29. Bousquet J, Anto JM, Wickman M, Keil T, Valenta R, Haahtela T, et al. Are allergic multimorbidities and IgE polysensitization associated with the persistence or re-occurrence of foetal type 2 signalling? The MeDALL hypothesis. Allergy. 2015;70(9):1062-78.

30. Bousquet J, Anto JM, Akdis M, Auffray C, Keil T, Momas I, et al. Paving the way of systems biology and precision medicine in allergic diseases: the MeDALL success story. Allergy 2016;71(11):1513-25.
31. Abbasi J. FDA extends authority to e-cigarettes: implications for smoking cessation? JAMA 2016:316(6):572-4.

32. Bousquet J, Knani J, Hejjaoui A, Ferrando R, Cour P, Dhivert H, et al. Heterogeneity of atopy. I. Clinical and immunologic characteristics of patients allergic to cypress pollen. Allergy. 1993;48(3):183-8.

33. Polosa R, Campagna D, Sands MF. Counseling patients with asthma and allergy about electronic cigarettes: an evidence-based approach. Ann Allergy Asthma Immunol. 2016;116(2):106-11.

\section{Submit your next manuscript to BioMed Central and we will help you at every step:}

- We accept pre-submission inquiries

- Our selector tool helps you to find the most relevant journal

- We provide round the clock customer support

- Convenient online submission

- Thorough peer review

- Inclusion in PubMed and all major indexing services

- Maximum visibility for your research

Submit your manuscript at www.biomedcentral com/submit 